\title{
A METHOD DEVELOPMENT FOR IMPROVING THE STABILITY OF VEGETABLE POLYPHENOL COMPLEXES FOR SEMI-FINISHED MINCED MEAT PRODUCTS WITH ANTIOXIDANT EFFECT
}

\author{
Alexander V. Gerasimov ${ }^{1}$, Bayana A. Bazhenova ${ }^{1 \star}$, Sesegma D. Zhamsaranova ${ }^{1}$, \\ Yulia Y. Zabalueva ${ }^{1}$, Nataliya D. Zambulaeva ${ }^{2}$, Anastasiya G. Burkhanova ${ }^{1}$ \\ ${ }^{1}$ East Siberia State University of Technology and Management, Ulan-Ude, Russia \\ ${ }^{2}$ The Institute of General and Experimental Biology of the Siberian Branch \\ of the Russian Academy of Sciences, Ulan-Ude, Russia
}

Key words: semi-finished minced meat products, offals, dried cowberry squeezing extract, total antioxidant content, polyphenols, sorption, losses during heat treatment, peroxide value, storage

\begin{abstract}
Polyphenolic vegetable complexes are active antioxidants and play an important role in the processes of free radicals quenching in the human body. The aim of the work was to develop an immobilization method as a way for improving the stability of polyphenols in dried cowberry squeezing extract (DCSE) and to develop semi-finished minced meat products with antioxidant effect without changing their nutritional value. Experiments were carried out to study the nutritional value of DCSE. The presence of a large number of polyphenolic compounds in DCSE and a high radical-binding ability of the extract were revealed. Based on the mathematical planning method, an offal paste composition was obtained, which was used to obtain pellets, and the formulation of semi-finished minced meat products with pellets was optimized. It was established that preliminary immobilization of DCSE on offal pellets components allows to increase the level of total antioxidant content in the minced meat. Subsequent heat treatment of semi-finished minced meat products produced from such minced meat showed an increase in stability and, thus, bioavailability of antioxidants and the possibility of obtaining a finished product with antioxidant effect. The antioxidant effect of cowberry squeezing extract in the meat system is proved: accumulation of lipid oxidative decomposition products in the meat system during storage of frozen semi-finished minced meat products was inhibited to a greater extent when using offal pellets with immobilized compounds of cowberry squeezing extract.

This work was carried out as part of the State Assignment of the Ministry of Education and Science of the Russian Federation No. 19.5486.2017/BCh and the "Young Scientists of ESSTU-2019» grant.
\end{abstract}

\section{Introduction}

In meat production, quick-frozen semi-finished minced meat products play a significant role. The advantage of this type of food is the possibility of long-term storage at low temperatures and quick preparation of a hot dish with high nutritional value.

At the same time, meat products do not have enough micronutrients in their composition and contain a certain amount of fat undergoing oxidative changes during storage, which may negatively affect the consumer properties of the product.

Constantly growing impact of chemical and non-chemical factors on the human body may decrease overall resistance of the body as a result of adaptive and protective mechanisms decompensation. Currently, one of the main cellular mechanisms of adaptation, i. e. the antioxidant system of the body, is of increasing interest of researchers.

The main source of antioxidants are products of vegetable origin: vegetables, fruits, juices, tea, etc. The antioxidant potential of products may be considered not only as functionality aspect, but also as one of the aspects of maintaining the quality of food products $[1,2,3,4,5,6,7,8,9,10]$. It should be noted that various profiles of the biologically active substances in vegetables, fruits and other vegetable products are explained not only by genetics, but also by other factors, including climatic, agricultural and other ones.

So, in $[11,12]$, the authors present the results of experimental studies evaluating the antioxidant activity of spicy herbs and onion. It is shown that the content of phenolic compounds in spicy herbs varies depending on the type of spice and on the extent of ripening. The authors conclude that the studied spicy herbs and onion have the ability to quench free radicals, prevent lipid oxidation, and exhibit reducing properties. The addition of spicy herbs (dill, parsley, basil, rosemary, oregano) and onion in food, including meat, allows enriching them with natural phenolic compounds.

Analysis and comparative evaluation of antioxidant activity and the content of prooxidant factors in various types of food raw materials and food products, primarily of vegetable origin, i. e. vegetables, fruits, drinks, juices, various crops, bakery and confectionery products, are given in a number of works $[13,14]$.

The work [15] studies total antioxidant content in water/ alcohol infusion of rose hips and barberry fruits and their 
use as food additives with antioxidant effect in the production of meat products.

Natural antioxidants have significant advantages over artificial ones: they contain a natural complex of biologically active substances in an available and digestible form. Such sources of antioxidants include many berries, for example, cowberry and cranberry, which are especially abundant in the Siberian forests [16].

One of the methods of berries processing is the production of juices, in the production of which $20-35 \%$ of waste is formed consisting of peel and seeds, i. e. so-called squeezing. In the best case, they may be used as livestock feed. In the worst case, they may be disposed. Although squeezing has the greatest antioxidant potential, since it contains a complex of vitamins ( $\mathrm{C}$ and $\mathrm{B}$ ), organic acids (benzoic, citric, malic, sorbic), minerals ( $\mathrm{Na}, \mathrm{K}, \mathrm{Ca}, \mathrm{Mn}$ ) and an increased content of dietary fiber $[17,18,19]$.

Recycled berry processing products have already widely used in wine industry in the form of pastes obtained from frozen squeezing [20]. It is proposed to use dried and crushed squeezing to enrich confectionery, bakery and meat products $[21,22,23]$. In the work, it was found that in terms of antioxidant properties (reducing strength by the FRAP method, antioxidant activity in the linoleic acid system, antioxidant activity by the DPPH method), squeezing is the best, while juices are significantly inferior to berries. Thus, squeezing is a valuable product containing more antioxidants than the initial raw material and having a high rate of antioxidant activity.

We have developed a technology for producing dried cowberry squeezing extract (DCSE) with antimicrobial and pronounced antioxidant effects [24]. In [25], the effect of dried extract from cranberry squeezing on the antioxidant and consumer properties of sugar cookies was investigated. The finished product, enriched with cranberry extract, was characterized by a high content of water-soluble antioxidants and had good consumer properties.

The level of bioflavonoids in food products depends both on the production technology and on storage duration and conditions of both raw materials and the products obtained from them. Cooking has a significant impact on the level of polyphenolic components. Simple peel cutting-off from fruits, vegetables, and berries may lead to a significant decrease in the content of bioflavonoids in them, which are usually present in significant quantities in the outer, and not in the inner part of fruits, berries, and vegetables [26].

Thus, the study of the actual content of compounds with antioxidant effect in finished products (after technological processing, cooking), increasing the efficiency and real assessment of the enriched dietary products contribution to the antioxidant status of the human body is extremely relevant.

The aim of this work was to develop a method for improving the stability of polyphenol complex isolated from cowberry squeezing and to formulate semi-finished minced meat products with high nutritional value and antioxidant effect.

\section{Materials and methods}

To conduct experimental studies, frozen beef offals from Buryat cattle were selected. The objects of research at the first stage were the beef offals, i. e. rumen, lungs, and diaphragm. The objects of research at the second stage were the dried cowberry squeezing extract (DCSE), minced meat and semifinished minced meat products.

At the first stage of the experiment, the nutritional value of beef offals was investigated; offal paste formulation was optimized, which included alginate-containing food additive as a texture-forming component, KF Stabipro FAT in the amount of $4 \%$. KF Stabipro FAT food additive was preliminarily subjected to hydration before its usage.

At the second stage, DCSE properties were studied, which was obtained by the following technology: squeezing formed after the juice was squeezed from cowberry growing in Transbaikalia was dried under infrared radiation at a temperature of $40{ }^{\circ} \mathrm{C}$ for $50 \mathrm{~min}$ to $10 \%$ moisture. Then, dried squeezing was subjected to grinding and further extraction with a water-alcohol solution using a microwave field. The obtained extracts were filtered, concentrated on a rotary evaporator at a temperature of $45^{\circ} \mathrm{C}$ and then dried to obtain a powder [24].

At the next stage, in the course of the experiment, minced meat samples were prepared according to the formulation, which consisted of 2-grade trimmed beef and semi-fat trimmed pork (Control 1). Test 1 - samples of steaks from minced meat, into which $0.2 \%$ DCSE was added. Control 2 - steaks from minced meat with pellets (based on ground beef rumen, lungs, diaphragm, alginatecontaining additive). Test 2 - steak sample with pellets, on the components of which $0.2 \%$ DCSE was preliminarily immobilized. Pellets have been used to replace basic raw materials and to study the possibility of DCSE polyphenols sorption on protein molecules. Alginate-containing additive was used as an enhancer of functional and technological characteristics.

To evaluate the antioxidant activity of the studied samples, the amperometric measurement of total antioxidant content (TAC) in quercetin equivalent was performed. To determine TAC, sample preparation was carried out by aqueous extraction of the test samples with bidistilled water to isolate water-soluble compounds with antioxidant effect. Total antioxidant content was determined by amperometric method using Tsvet Yauza-01-AA instrument. To construct calibration graphs, quercetin solutions were used [27].

The extraction efficiency was estimated by the number of phenolic compounds isolated with spectrophotometric method using the Folin-Ciocalteu reagent. The content of benzoic acid was investigated using the HPLC method. The $\mathrm{pH}$ value was determined by potentiometric method.

A spectrophotometric method with 2,2-diphenyl-1-picryl hydrazyl chromogen radical (DPPH) was used to determine the radical-binding ability (RBA) of the extracts. The method is based on the reaction of DPPH dissolved in ethanol with an antioxidant sample. Radical-binding ability was calculated 
as $\mathrm{EC}_{50}$, i.e. the concentration of the initial extract required for quenching of 50\% DPPH radicals [28].

During the experiments, the physical and chemical parameters characterizing the quality of semi-finished meat product were studied. Protein content was evaluated by the Kjeldahl method. Collagen content was evaluated by the amount of oxyproline (treating the analyzed sample with a solution of perchloric acid for 4 hours under heating conditions in a water bath at $100{ }^{\circ} \mathrm{C}$, neutralization of the reaction mixture with sodium hydroxide, addition of propanol-2 and a solution of chloramine- $T$ in acetatecitrate buffer, followed by treatment with a solution of paradimethylaminobenzaldehyde in a mixture of $57 \%$ solution of perchloric acid and propanol-2, heating for 25 minutes at $60{ }^{\circ} \mathrm{C}$ and photometric analysis of the resulting colored solution). Elastin content was evaluated by gravimetric method, and fat by Soxhlet method. Moisture was evaluated by drying to constant weight, ash by dry ashing, and amino acid composition by chromatographic method.

Sensory analysis of semi-finished minced meat products were carried out according to a 9-point scale. Peroxide value in the samples was determined by a method based on the interaction of the oxidation products of fatty raw materials (peroxides and hydroperoxides) with potassium iodide in a solution of acetic acid and chloroform, followed by quantitative determination of the iodine released by the sodium thiosulfate solution with the titrimetric method.

The experiments were performed in triplicate; statistical processing of the obtained experimental data was carried out using the Microsoft Excel software.

\section{Results and discussion}

In order to improve stability of the antioxidant polyphenolic complex from cowberry squeezing, offal paste based pellets were developed, into which an extract was added to sorb biologically active substances of DCSE on the protein components of the paste. When developing the formulation of pellets, the aim was to adequately replace part of raw meat with offals. Currently, low-value offals, such as lungs, rumen, etc., are either sold frozen or transferred to the production of feed. Although it is known that offals contain valuable proteins. Table 1 presents the content of the main components in the studied offals obtained when slaughtering Buryat cattle.

Table 1. The chemical composition of beef offals

\begin{tabular}{|l|c|c|c|}
\hline \multirow{2}{*}{ Parameters } & \multicolumn{3}{|c|}{ Offals } \\
\cline { 2 - 4 } & Lung & Rumen & Diaphragm \\
\hline & Mass fraction,\% \\
\hline moisture & $73.85 \pm 1.56$ & $75.51 \pm 1.18$ & $72.53 \pm 1.41$ \\
\hline total protein, including & $18.43 \pm 0.91$ & $17.09 \pm 0.78$ & $18.84 \pm 1.12$ \\
- collagen & $6.64 \pm 0.22$ & $12.03 \pm 0.52$ & $5.15 \pm 0.21$ \\
\hline - elastin & $1.02 \pm 0.03$ & $0.61 \pm 0.04$ & $0.3 \pm 0.01$ \\
\hline fat & $5.85 \pm 0.10$ & $5.65 \pm 0.11$ & $7.08 \pm 0.11$ \\
\hline ash & $1.87 \pm 0.12$ & $1.77 \pm 0.11$ & $1.74 \pm 0.12$ \\
\hline
\end{tabular}

The data in Table 1 indicate that the moisture content in rumen is $1.66 \%$ higher than in lungs and $2.98 \%$ higher than in diaphragm. Protein content is quite high in all types of offals and amounted to 68 to $77 \%$, the difference was within statistical error. Offal proteins include both complete ones and low-value connective tissue proteins, which play a role in the gastrointestinal processes.

To analyze the protein composition of beef offals, comparative diagrams were constructed (Fig. 1), which clearly show that complete proteins, such as myoglobin, albumin, globulin and others, prevail in the lungs and diaphragm, which amounted to 63.4 to $71.1 \%$. Rumen generally contains low-value proteins, mainly collagen $(70.4 \%)$, however, complete proteins are present, and their mass fraction is almost 30\%.

In accordance with the aim, the possibility of creating pellets based on offal paste for the adequate replacement of minced meat and the immobilization of biologically active substances from dried cowberry squeezing extract on pellet protein components to increase their stability during processing and heat exposure was studied.

To achieve this, studies were carried out to replace a portion of the meat in the formulation of minced steak with pellets developed on the basis of offal paste and alginatecontaining additive. The replacement is justified not only by the rational use of animal by-products, but also by reducing the cost of the finished product and the need to introduce polyphenolic micronutrients into the meat product in an effective dose. To preserve the nutritional value of the product and adequate meat replacement, the method of mathematical

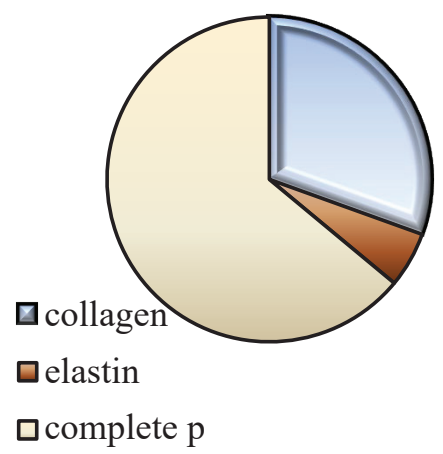

a

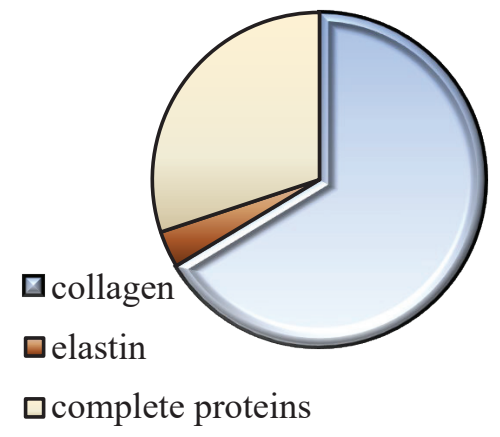

b

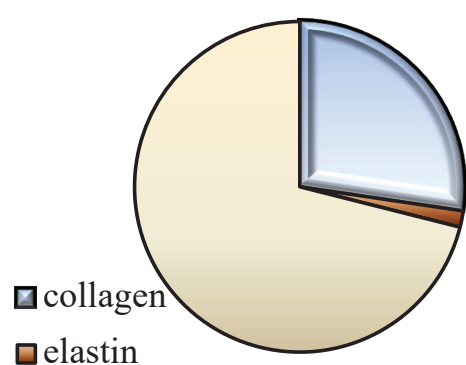

$\square$ complete proteins

Figure 1. The ratio of complete and low-value proteins in offals obtained from slaughter of Buryat cattle: a) lungs, b) rumen, c) diaphragm 
simulation of minced steak formulation and optimization of the chemical composition was used.

Offals were prepared by thawing, cleaning and washing, then finely ground to a paste-like consistency. To determine the optimal ratio of offals in the composition of the paste, its formulation was optimized using the «Solution Search» tool in Microsoft Excel software, which resulted in the following ratio: diaphragm $40 \%$, rumen $30 \%$, lung $30 \%$. The paste was red, without any off-odor. To improve the functional and technological characteristics of the paste used, KF Stabipro FAT food additive containing sodium alginate, calcium pyrophosphate and calcium sulfate was introduced. To stabilize the texture of the resulting mixture, it was kept in a refrigerator at a temperature of $5^{\circ} \mathrm{C}$ for 12 hours. The obtained hardened mass had an elastic consistency, red color and no off-odor. Then it was passed through a meat grinder ( $3 \mathrm{~mm}$ diameter) and so-called pellets were obtained, which were added into the composition of minced meat for steaks.

Formulation of minced steaks with pellets was developed by computer optimization using an integrated model that takes into account the chemical and amino acid composition of the ingredients.

To carry out the calculation of the formulation, a mathematical model was developed that included both the initial (protein, fat, amino acid content - Table 2) and output data (optimal ratio of the formulation ingredients and the value of the optimality test).

Table 2. The content of the main nutrient components

\begin{tabular}{|l|c|c|c|}
\hline \multicolumn{1}{|c}{ Parameters } & $\begin{array}{c}\text { 2-Grade } \\
\text { trimmed } \\
\text { beef }\end{array}$ & $\begin{array}{c}\text { Semi-fat } \\
\text { trimmed } \\
\text { pork }^{*}\end{array}$ & Pellets \\
\hline Protein content,\% & 18.8 & 12.6 & 8.4 \\
\hline Fat content,\% & 7.5 & 33.5 & 4.6 \\
\hline
\end{tabular}

Essential amino acids, g/100 g

protein:

\begin{tabular}{|l|c|c|c|}
\hline Valine & 10.9 & 9.2 & 2.2 \\
\hline Isoleucine & 8.2 & 6.9 & 1.9 \\
\hline Leucine & 16.6 & 9.9 & 3.8 \\
\hline Lysine & 16.7 & 12.1 & 3.4 \\
\hline Methionine + cystine & 6.1 & 4.2 & 1.6 \\
\hline Threonine & 8.2 & 6.1 & 1.5 \\
\hline Tryptophan & 2.2 & 1.8 & 0.4 \\
\hline Phenylalanine + tyrosine & 14.8 & 10.2 & 2.9 \\
\hline Total essential amino acids & 83.7 & 60.4 & 17.7 \\
\hline ^ data from literature & & & \\
\hline
\end{tabular}

The conditions in the mathematical model of the optimal steaks composition are described as a system of inequalities, where:

$\mathrm{x}_{1}$ is 2 -grade trimmed beef;

$\mathrm{x}_{2}$ is semi-fat trimmed pork;

$\mathrm{x}_{3}$ is offal pellets.

The limitations for the system of inequalities are presented by the indicators of biological value and chemical composition (Table 3 ).
Table 3. Limitations for the mathematical model of formulation

\begin{tabular}{|l|c|c|}
\hline \multirow{2}{*}{ Parameters } & \multicolumn{2}{|c|}{ Content } \\
\hline Protein content,\% & min & $\max$ \\
\hline Fat content, $\%$ & 14.0 & 58.0 \\
\hline
\end{tabular}

Essential amino acids, $\mathrm{g} / 100 \mathrm{~g}$ protein:

\begin{tabular}{|l|c|c|}
\hline Valine & 5.0 & no limitation \\
\hline Isoleucine & 4.0 & no limitation \\
\hline Leucine & 7.0 & no limitation \\
\hline Lysine & 5.5 & no limitation \\
\hline Methionine + cystine & 3.5 & no limitation \\
\hline Threonine & 4.0 & no limitation \\
\hline Tryptophan & 1.0 & no limitation \\
\hline Phenylalanine + tyrosine & 6.0 & no limitation \\
\hline Total essential amino acids & 36.0 & no limitation \\
\hline
\end{tabular}

The system of inequalities in the mathematical model (complex model) of formulation for the designed finished product is presented as follows:

1. $14.0 \leq 18.8 \mathrm{x}_{1}+12.6 \mathrm{x}_{2}+8.4 \mathrm{x}_{3} \leq 58.0$ (by protein content)

2. $0 \leq 7.5 \mathrm{x}_{1}+33.5 \mathrm{x}_{2}+4.6 \mathrm{x}_{3} \leq 20.0$ (by at content)

3. $5.0 \leq 10.9 \mathrm{x}_{1}+9.2 \mathrm{x}_{2}+2.2 \mathrm{x}_{3}$ (by valine content). etc.

To simplify the inequalities, the following is assumed: $x=x_{i} / 100$, where $i=1 \div 3$. Thus, the following natural requirement for obtaining a production unit arises:

$$
\mathrm{x}_{1}+\mathrm{x}_{2}+\mathrm{x}_{3}=1.0
$$

The objective function is as follows:

$$
\begin{aligned}
& \mathrm{F}_{\text {ц }} \text { (Total essential amino acids) }= \\
& =83.7 \mathrm{x}_{1}+60.4 \mathrm{x}_{2}+17.7 \mathrm{x}_{3} \rightarrow \mathrm{M}
\end{aligned}
$$

As a result of problem solving, the formulation options of the finished product were obtained presented in Table 4 .

Table 4. Formulation options

\begin{tabular}{|l|c|c|c|c|c|c|c|}
\hline $\begin{array}{l}\text { Formulation } \\
\text { ingredients }\end{array}$ & 1 & 2 & 3 & 4 & 5 & 6 & 7 \\
\hline $\begin{array}{l}\text { 2-Grade } \\
\text { trimmed beef }\end{array}$ & 70.0 & 65.0 & 60.0 & 55.0 & 50.0 & 45.0 & 40.0 \\
\hline $\begin{array}{l}\text { Semi-fat } \\
\text { trimmed pork }\end{array}$ & 20.0 & 20.0 & 20.0 & 20.0 & 20.0 & 20.0 & 20.0 \\
\hline Pellets & 10.0 & 15.0 & 20.0 & 25.0 & 30.0 & 35.0 & 40.0 \\
\hline Total & 100.0 & 100.0 & 100.0 & 100.0 & 100.0 & 100.0 & 100.0 \\
\hline
\end{tabular}

In accordance with Table 4, samples of minced meat and minced steaks were produced and their sensory characteristics were analyzed. The analysis showed that the addition of pellets at the level of more than $15 \%$ reduces the overall sensory quality of the finished products; therefore, for the further experiments, option 2 formulation was chosen.

The predicted quality indicators of the developed minced steaks with pellets, which were obtained when solving the inequalities of the mathematical model, are shown in Table 5. 
Table 5. Quality indicators obtained when solving the mathematical model

\begin{tabular}{|l|c|c|}
\hline \multicolumn{1}{|c|}{ Parameters } & \multicolumn{2}{c|}{ Content } \\
\hline & $\begin{array}{c}\text { Steaks } \\
\text { (Control 1) }\end{array}$ & $\begin{array}{c}\text { Steaks } \\
\text { with pellets } \\
\text { (Control 2) }\end{array}$ \\
\hline $\begin{array}{l}\text { Protein content, \% } \\
\text { Fat content, \% }\end{array}$ & 17.56 & 16.00 \\
\hline $\begin{array}{l}\text { Total essential amino acids, } \mathrm{g} / 100 \mathrm{~g} \\
\text { protein: }\end{array}$ & 12.70 & 12.27 \\
\hline
\end{tabular}

The data showed that as a result of formulation development for minced steaks with pellets, their composition is close to the content of the main substances in meat steaks.

At the next stage, the possibility of effective enrichment of semi-finished minced meat products with DCSE compounds was studied. The dry extract is obtained from by-products of juice production: the remaining squeezing after separation of the liquid pulp is not further processed and is considered waste. Squeezing, which consists of cowberry peel and seeds contains the largest number of biologically active compounds with high pharmacological characteristics [25].

DCSE preparation technology is presented in [24]. DCSE is a free-flowing mass of sweet and sour, harsh flavor with cowberry aroma and maroon color. The dry texture of the concentrated extract provides a high concentration of biologically active substances, so even a small dose of DCSE in a meat product may provide it with functional properties; however, some technological difficulties are associated with this.

Table 6 presents physical and chemical characteristics of squeezing extract from cowberry growing in Transbaikalia.

Table 6. Physical and chemical characteristics of dried cowberry squeezing extract

\begin{tabular}{|l|c|}
\hline \multicolumn{1}{|c|}{ Parameters } & \multicolumn{1}{c|}{ Value } \\
\hline $\mathrm{pH}$ value & $3.23 \pm 0.07$ \\
\hline Total antioxidant content, $\mathrm{mg} / \mathrm{g}$ & $382.5 \pm 8.4$ \\
\hline $\begin{array}{l}\text { Content, } \% \text { : } \\
\text { moisture }\end{array}$ & $4.51 \pm 0.07$ \\
\hline \multicolumn{1}{|c|}{ polyphenols } & $6.62 \pm 0.03$ \\
\hline benzoic acid & $1.33 \pm 0.01$ \\
\hline
\end{tabular}

The data in Table 6 indicate that cowberry squeezing extract has a low $\mathrm{pH}$ of 3.23 due to the high concentration of organic acids in DCSE. Significant total antioxidant content was found, which amounted to $382.5 \mathrm{mg} / \mathrm{g}$ of dry extract. The main components with antioxidant properties are polyphenols, the concentration of which is up to $6.62 \%$. More than half of the polyphenols in cowberry are anthocyanins (3.59\%), which are able to quench almost all types of reactive oxygen and nitrogen species four times more effective than ascorbate and $\alpha$-tocopherol.

A high content of benzoic acid (1.33\%) was found in DCSE, which is typical for cowberry fruits. That is why the berries may be stored for a long time without spoilage. Benzoic acid is known to have antimicrobial and even bactericidal effects.
Free radicals that occur in the body as a result of a homolytic rupture of chemical bonds due to a number of conditions (temperature, radiation, stress, improper nutrition, etc.) have a maximum destructive effect on human cells. Level of free radicals binding characterizes the ability of the antioxidant to resist the development of the so-called oxidative stress. Among several methods for studying antiradical activity, the method using 2,2-diphenyl-1-picryl hydrazyl is widely used and is the most acclaimed [29]. Figure 2 shows radical-binding ability of dried cowberry squeezing extract.

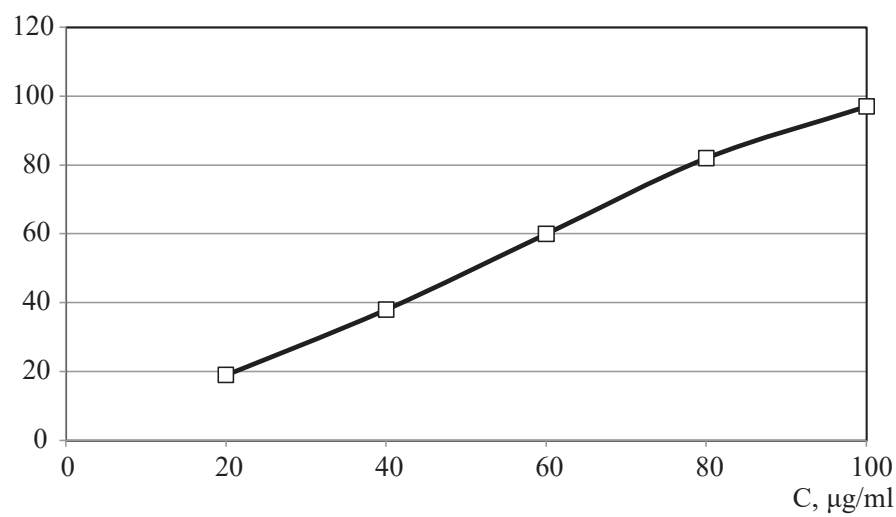

Figure 2. Radical-binding ability of DCSE

According to the data obtained, 50\% of DPPH radical binding is achieved at a concentration of cowberry extract of $50.5 \mu \mathrm{g} / \mathrm{ml}$, and $80 \%$ at $80.3 \mu \mathrm{g} / \mathrm{ml}$. The high antiradical activity of apple and grape squeezing, which exceed the corresponding indices of berries and juices, is reported by the authors in [30].

To enrich semi-finished minced meat products with antioxidants, experimental studies were conducted on the addition of DCSE in the amount of $0.2 \%$ in dry form, hydrated in process water, and preliminarily sorbed on offal paste ingredients. Samples of minced meat were prepared and total antioxidant content was studied in minced meat and finished minced steaks after steam treatment at $80-85^{\circ} \mathrm{C}$ for 20 minutes (Figure 3).

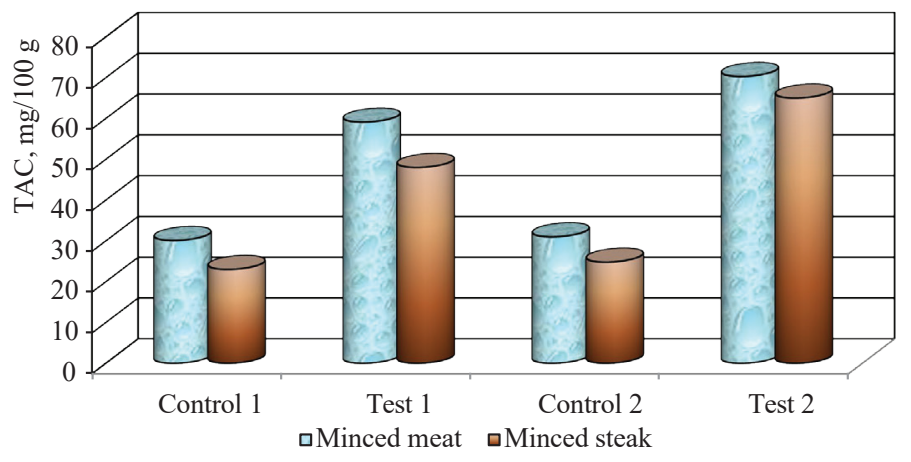

Figure 3. Total antioxidant content in minced meat and semi-finished minced meat products: Control 1 - steaks; Test 1 - steaks with $0.2 \%$ DCSE; Control 2 - steaks with pellets; Test 2 - steaks with pellets containing $0.2 \%$ sorbed DCSE

The data presented in Figure 3 indicate that antioxidants are present in minced meat of steak (Control 1) in an amount of $30.1 \mathrm{mg} / 100 \mathrm{~g}$ of minced meat. With the introduction 
of $0.2 \%$ DCSE (Test 1 ), TAC increased almost twice and amounted to $59.1 \mathrm{mg} / 100 \mathrm{~g}$ of minced meat.

When adding pellets without DCSE to minced meat (Control 2), the antioxidant content remained almost unchanged compared to Control 1 and amounted to $31.0 \mathrm{mg} / 100 \mathrm{~g}$ of minced meat. With the addition of $0.2 \%$ DCSE sorbed on pellets (Test 2), TAC increased 2.27 times and amounted to $70.3 \mathrm{mg} / 100 \mathrm{~g}$ of minced meat. The increase in total antioxidant content with preliminarily immobilization of DCSE compounds compared to simple addition of the dry extract was $19 \%$, which indicates the efficiency of polyphenolic compounds sorption when pre-incubated with pellets. Proteins of connective tissue in offals, mainly collagen, have high sorption abilities. Fine grinding of offals to a paste also provides optimal conditions for sorption of polyphenols. The collagen molecule contains a significant amount of diamino and amino dicarboxylic acids with a large number of side polar groups that are able to bind other molecules, e. g. polyphenols. Furthermore, the introduction of alginate-containing additive suggests the possibility of retaining polyphenolic compounds by sodium alginate polymolecules.

Further, antioxidants losses during heat treatment of minced steaks were studied. Since these are products without a cover, there is a high probability of TAC losses in finished products intended for consumption. The data presented in Figure 3 indicated that all samples showed a decrease in TAC after heat treatment. Thus, in the finished product (control 1), there was a decrease in antioxidant content by $23.6 \%$ compared with minced meat. In Test 1 , with the addition of $0.2 \%$ DCSE, the losses were less (18.8\%), apparently due to the initial high TAC level (almost 2 times higher compared to control).

Based on the data in Figure 3, TAC reduction after heat treatment in the finished product with pellets (Control 2) was $20 \%$. A significant reduction in TAC losses in the finished product (Test 2) should be noted, in which DCSE was preliminarily sorbed on pellets. Losses amounted to only $7.5 \%$.

The data presented prove the effectiveness of DCSE polyphenols immobilization, as losses in Test 2 decreased by 2.5 times compared with Test 1 .

In accordance with the current «Recommended levels of consumption of food and biologically active substances. Guidelines. MR 2.3.1.1915-04» (approved by Rospotrebnadzor 07/02/2004), the average consumption rate of antioxidant polyphenols for a healthy population is $250-300 \mathrm{mg} /$ day. In our proposed formulation of minced steaks containing pellets with immobilized DCSE, the TAC level is $70.3 \mathrm{mg} / 100 \mathrm{~g}$ of the finished product, which provides 23.4 to $28.1 \%$ of the daily requirement for antioxidants and represents a functional food with antioxidant effect.

The sensory characteristics of finished minced steaks were investigated (Figure 4).

As shown in Figure 4, the studied samples almost did not differ in their sensory characteristics. Test 1 sample was as close as possible to Control 1 sample. Control 2 and Test $2 \mathrm{had}$ more dense texture, elastic, pleasant to the taste. As a result, overall estimates of indicators characterizing the consumer properties of the finished product turned out to be at the same level in the control and test samples.

Polyphenols also have antioxidant activity; in this connection, the effect of DCSE on the dynamics of peroxide value during storage of minced steaks was investigated. For a comparative study, a steak sample with pellets (Control) and a steak sample with pellets containing immobilized DCSE (Test) were selected. Figure 5 shows the influence of DCSE on the dynamics of fat oxidation process in the control and test minced steaks.

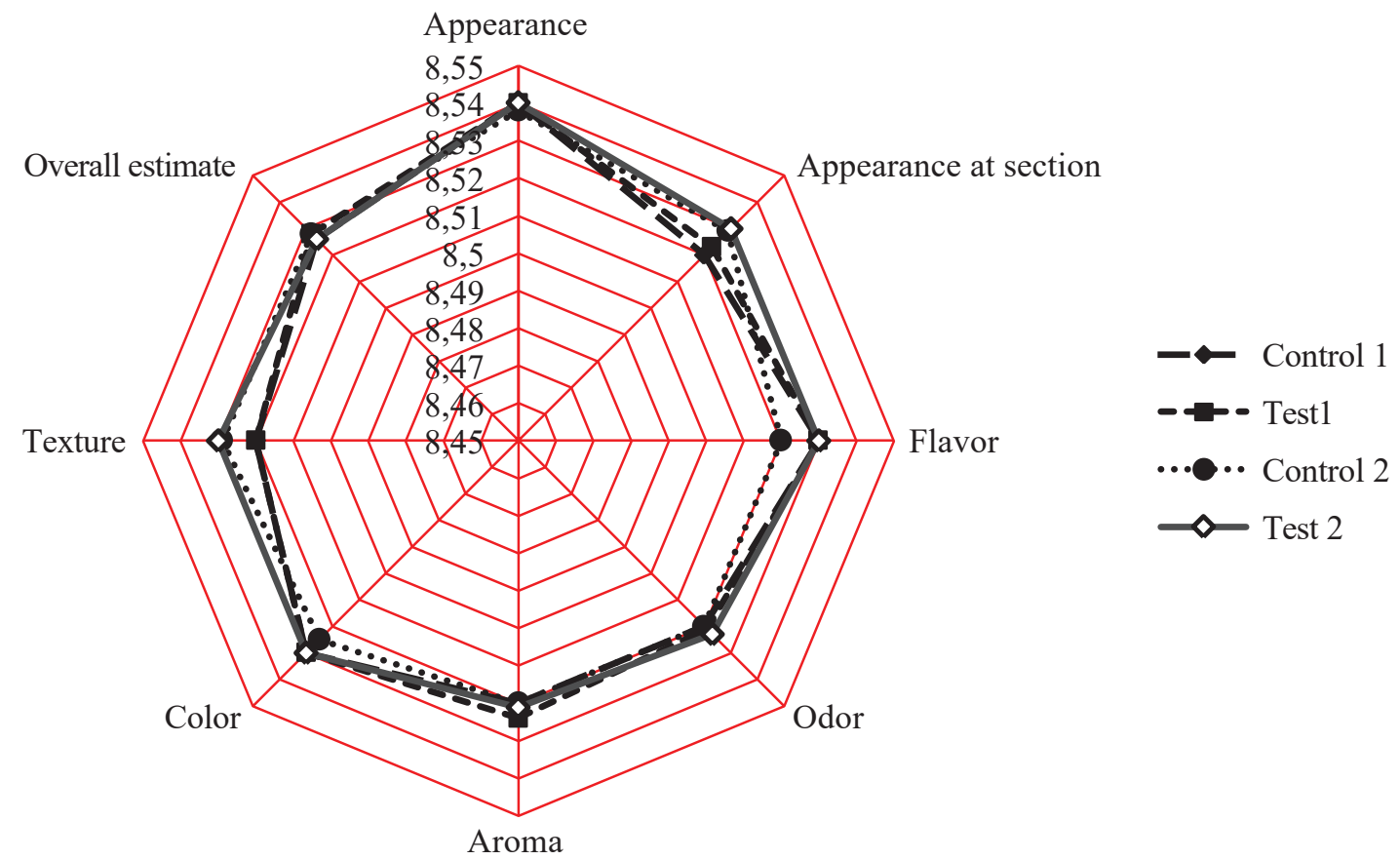

Figure 4. Sensory parameters of semi-finished minced meat products: Control 1 - steaks; Test 1 - steaks with $0.2 \%$ DCSE; Control 2 - steaks with pellets; Test 2 - steaks with pellets containing $0.2 \%$ sorbed DCSE 


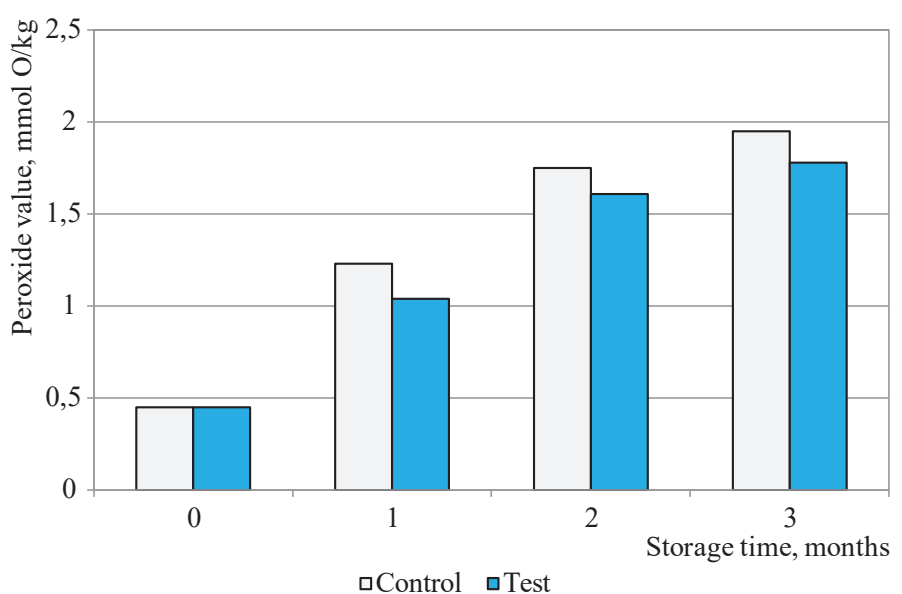

Figure 5. Effect of DCSE on the change in peroxide value of semifinished minced meat products during storage

Quick-frozen semi-finished minced meat products in sealed packaging may be stored for three months at a temperature of minus $18^{\circ} \mathrm{C}$. According to the data presented in Figure 5, there is an irreversible process of fat self-oxidation in semi-finished products with the accumulation of primary fat degradation products. Immediately after production, peroxide value in test samples was $0.45 \mathrm{mmol} \mathrm{O} / \mathrm{kg}$. After storage of the frozen finished products at a temperature of minus $18{ }^{\circ} \mathrm{C}$ for one month, the peroxide value increased in the control up to the level of $1.23 \mathrm{mmol} \mathrm{O} / \mathrm{kg}$, and in the test sample up to $1.04 \mathrm{mmol} \mathrm{O} / \mathrm{kg}$. After two months of oxidative process, peroxide value in the control was already 1.75 $\mathrm{mmol} \mathrm{O} / \mathrm{kg}$ ( 3 times increase), and in the test $1.61 \mathrm{mmol} \mathrm{O} /$ $\mathrm{kg}$ (2.5 times increase). After months, when the shelf life of frozen semi-finished minced meat products was reached, the peroxide value in the control sample increased to 1.95 $\mathrm{mmol} \mathrm{O} / \mathrm{kg}$, while remaining within the prescribed range. In the test sample, after three months, the peroxide value was $1.78 \mathrm{mmol} \mathrm{O} / \mathrm{kg}$. Based on the data obtained, the effect of lipid self-oxidation inhibition in the meat system with the addition of DCSE was found. The beneficial effect of natural antioxidants on oxidative reactions inhibition during storage of both minced semi-finished meat products and finished products was noted in [31].

\section{Conclusion}

Thus, as a result of experimental studies, it was found that the addition of DCSE, which has a high antioxidant effect, into the formulation of semi-finished minced meat products allows obtaining a finished product with an antioxidant effect. It was established that preliminary mixing of DCSE with offal-based pellets and subsequent ageing of the mixture make it possible to increase the content of antioxidants both in semi-finished and in finished products due to sorption of DCSE polyphenols on ingredients of offal paste. Sorption of polyphenols allows improving antioxidant stability during the technological and thermal processing of minced steaks, thereby providing 23.4 to $28.1 \%$ of the daily requirement for antioxidants when consuming 100 grams of the finished product. The use of pellets allows not only to reduce the consumption of basic raw materials, but also to ensure adequate preservation of the nutritional value of the finished meat product. Antioxidants of DCSE have antioxidative properties and reduce the accumulation of primary lipid degradation products, thus ensuring high consumer properties of the finished product and the possibility of shelf life extending for quick-frozen semi-finished minced meat products.

\section{Acknowledgment}

This work was carried out as part of the State Assignment of the Ministry of Education and Science of the Russian Federation No. 19.5486.2017/BCh and the «Young Scientists of ESSTU-2019» grant.

\section{REFERENCES}

1. Tohma, H., Gülçin, İ., Bursal, E., Gören, A.C., Alwasel, S.H., Köksal, E. (2017). Antioxidant activity and phenolic compounds of ginger (Zingiber officinale Rosc.) determined by HPLC-MS/ MS. Journal of food measurement and characterization. 11(2), 556-566. DOI: 10.1007/s11694-016-9423-z

2. Zhirkova, E.V., Skorokhodova, M.V., Martirosyan, V.V., Sotchenko, E.F., Malkina, V.D., Shatalova, T.A. (2016). Chemical composition and antioxidant activity of corn hybrids grain of different pigmentation. Foods and raw materials, 1(4), 85-91. DOI: 10.21179/2308-4057-2016-2-85-91

3. Lisitsyn, A.B., Chernukha, I.M., Lunina, O.I. (2018). Modern trends in the development of the functional food industry in Russia and abroad. Theory and practice of meat processing, 3(1), 2945. DOI: 10.21323/2414-438X-2018-3-1-29-45 (In Russian) 4. Kakouri, E., Daferera, D., Paramithiotis, S., Astraka, K., Drosinos, E.H., Polissiou, M.G. (2017). Crocus sativus L. tepals: The natural source of antioxidant and antimicrobial factors. Journal of applied research on medicinal and aromatic plants, 4, 66-74. DOI: 10.1016/j.jarmap.2016.09.002

5. Ayoub, Z., Mehta, A., Mishra, S.K., Ahirwal, L. (2017). Medicinal plants as natural antioxidants: a review. Journal of botanical society, 48.

6. Baiano, A., del Nobile, M.A. (2015). Antioxidant compounds from vegetable matrices: Biosynthesis, occurrence, and extraction systems. Critical reviews in food science and nutrition, 56(12), 2053-2068. DOI: 10.1080/10408398.2013.812059
7. Li, Y., Zhang, J.J., Xu, D.P., Zhou, T., Zhou, Y., Li, S., Li, H.B. (2017). Bioactivities and health benefits of wild fruits. International journal of molecular sciences, 17(8), 1258. DOI: 10.3390/ ijms17081258

8. Chan, E.W.C., Tan, Y.P., Chin, S. J., Gan, L.Y., Kang, K.X., Fong, C.H., How, Y.C. (2014). Antioxidant properties of selected fresh and processed herbs and vegetables. Free radicals and antioxidants, 4(1), 39-46. DOI: 10.5530/fra.2014.1.7

9. Esan, Y.O., Sade, O.O., Victor, E.N., Oluranti, O.O. (2018). Functional and antioxidant properties of raw and popped Amaranth (Amaranthus cruentus) seeds flour. Annals. Food science and technology, 19(2), 399-408.

10. Akbarirad, H., Ardabili, G.A., Kazemein, i S.M., Khaneghah, M.A. (2016). An overview on some of important sources of natural antioxidants. International food research journal, 23(3), 928-933. 11. Borisova, A.V., Makarova, N.V. (2013). Rating antioxidant activity of herbs and onions. Storage and processing of farm products, 8, 32-35. (In Russian)

12. Oswel, N.J., Thippareddi, H., Pegg, R.B. (2018). Practical use of natural antioxidants in meat products in the U.S.: A review. Meat Science, 11, 145:469-479. D0I: 10.1016/j.meatsci.2018.07.020

13. Yashin, Ya.I., Ryzhnev, v. Yu., Yashin, A. Ya., Chernousova, N.I. (2009). Natural antioxidants. Content in food products and impact on human health and aging. Moscow: Translit. - 212 p. ISBN 978-5-94976-727-6 (In Russian) 
14. Kebede, M., Admassu, Sh. (2019). Application of antioxidants in food processing industry: options to improve the extraction yields and market value of natural products. Advances in food technology and nutritional sciences, 5(2), 38-49. DOI: 10.17140/ AFTNSOJ-5-155

15. Zabalueva, Yu. Yu., Meleshkina, N.V., Bazhenova, B.A., Danilov, M.B. (2017). One of the ways of enrichment of meat products by natural antioxidants. Vsyo o myase, 2, 12-15. (In Russian) 16. Bazarnova, Yu.G., Polyakov, K. Yu. (2009). Study of antioxidant activity of natural substances. Storage and processing of farm products, 3, 31-36. (In Russian)

17. Izosimova, I.V. (2004). Scientific and practical basis for the rational use of cowberry (Vaccinium vitis-idaea) and cranberry (Oxycoccus palustris). Author's abstract of the dissertation for the scientific degree of Candidate of Biological Sciences. Krasnoyarsk: Krasnoyarsk State Trade and Economic Institute. - 24 p. (In Russian)

18. Lutikova, M.N. (2013). Composition studying of biologically active ingredients in wild berries of Vaccinium vitis-idaea and Oxycoccus palustris depending on their degree of maturity and storage conditions. Author's abstract of the dissertation for the scientific degree of Candidate of Chemical Sciences. Surgut: Surgut State University. - 24 p. (In Russian)

19. Bazarnova, Yu.G. (2012). Biologically active substances of wild-growing raw materials: stabilization and application in food technologies. St. Petersburg: St. Petersburg State University of Low-Temperature and Food Technologies. - 215 p. (In Russian)

20. Kolman, O. Ya., Ivanova, G.V. (2013). Methods for preserving the secondary raw materials of wild cowberries and cranberries. Bulletin of KrasGAU, 5(80), 218-223. (In Russian)

21. Kolman, O. Ya., Ivanova, G.V., Tsuglenok, N. V. Reduced calorie muffins. Patent RF, no.2012117932. 2013. (In Russian)

22. Kolman, O. Ya., Ivanova, G.V., Tsuglenok, N. V. Marmalade and berry masses. Patent RF, no.2012118185. 2013. (In Russian)
23. Izosimova, I.V., Ivanova, G.V., Sergacheva, O.M. (2001). The use of environmentally friendly secondary vegetable raw materials in the production of pastes. IV International Symposium "New and unconventional plants and prospects for their use", 3,469471. (In Russian)

24. Zambulaeva N. D., Zhamsaranova, S.D. A method of obtaining a dry cowberry or cranberry squeezing extract. Patent RF, no. 2626565. 2017. (In Russian)

25. Zambulaeva N.D., Zhamsaranova, S.D. (2016). Dry extract from squeezing of wild berries as a promising ingredient in functional nutrition products. XV International Conference of Young Scientists "Food Technology and Biotechnology". Conference proceedings, 107-109 pp. ISBN 978-5-98946-172-1 (In Russian) 26. Tutelyan, V.A., Lashneva, N.V. (2013). Biologically active substances of plant origin. Flavonols and flavones: prevalence, dietary sources and consumption. Voprosy Pitaniia, 82(1), 4-23. (In Russian)

27. Yashin, A. Ya. (2008). Injection-flow system with amperometric detector for the selective determination of antioxidants in foods and beverages. Russian chemical journal, 52(2), 130-135. (In Russian)

28. Majewska, M., Skrzycki, M., Podsiad, M., Czeczot, H. (2011). Evaluation of antioxidant potential of flavonoids: an in vitro study. Acta Poloniae Pharmaceutica, 68(4), 611-615.

29. Makarova, N.V., Valiulina, D.F., Azarov, O.I., Kuznetsov, A.A. (2018). Comparative studies: content of phenolic compounds, flavonoids and antioxidant activity in apples of different varieties. Khimija Rastitel'nogo Syr'ja, 2, 115-122. (In Russian)

30. Bykova, T.O., Makarova, N.V., Shevchenko, A.F. (2015). Chemical composition and antioxidant properties of apple and grape processing products, i.e. juice and squeezing. Storage and processing of farm products, 11, 20-22. (In Russian)

31. Yurikova, E. V., Savvateev, E. V., Savvateeva, L. Yu. (2013). Properties of additives for meat products. Food Industry, 11, 6062. (In Russian)

\section{AUTHOR INFORMATION}

Alexander V. Gerasimov — graduate student, Department «Technology of meat and canned products», East Siberia State University of Technology and Management. 670013, Ulan-Ude, Kluchevskaya str., 40. Tel: +7-983-432-59-58, E-mail: dimova_natalia1959@mail.ru

Bayana A. Bazhenova - doctor of technical sciences, professor, Professor, Department «Technology of meat and canned products», East Siberia State University of Technology and Management. 670013, Ulan-Ude, Kluchevskaya str., 40. Tel: +7-902-454-21-46, E-mail: bayanab@mail.ru *corresponding author

Sesegma D. Zhamsaranova - doctor of biological sciences, professor, Professor, Department «Biotechnology», East Siberia State University of Technology and Management. 670013, Ulan-Ude, Kluchevskaya str., 40.Tel: +7-924-652-28-58, E-mail: zhamsarans@mail.ru

Yuliya Yu. Zabalueva - candidate of technical sciences, docent, Docent, Department «Technology of meat and canned products», East Siberia State University of Technology and Management. 670013, Ulan-Ude, Kluchevskaya str., 40. Tel: +7-902-564-84-34, E-mail: aprilpolina@mail.ru

Natalya D. Zambulaeva - engineer, laboratory of Soil Biochemistry, The Institute of General and Experimental Biology of the Siberian Branch of the Russian Academy of Sciences. 670047, Улан-Удэ, Sahyanova str., 6. Tel: +7-902-161-22-80, E-mail: nzambulaeva@mail.ru

Anastasia G. Burkhanova — graduate student, Department «Technology of meat and canned products», East Siberia State University of Technology and Management/670013, Ulan-Ude, Kluchevskaya str., 40. Tel: +7-950-388-43-35, E-mail: nastenka_bur94@mail.ru

All authors bear responsibility for the work and presented data.

All authors made an equal contribution to the work.

The authors were equally involved in writing the manuscript and bear the equal responsibility for plagiarism.

The authors declare no conflict of interest.

Received 14.08.2019 Accepted in revised 23.09.2019 Accepted for publication 12.11.2019 